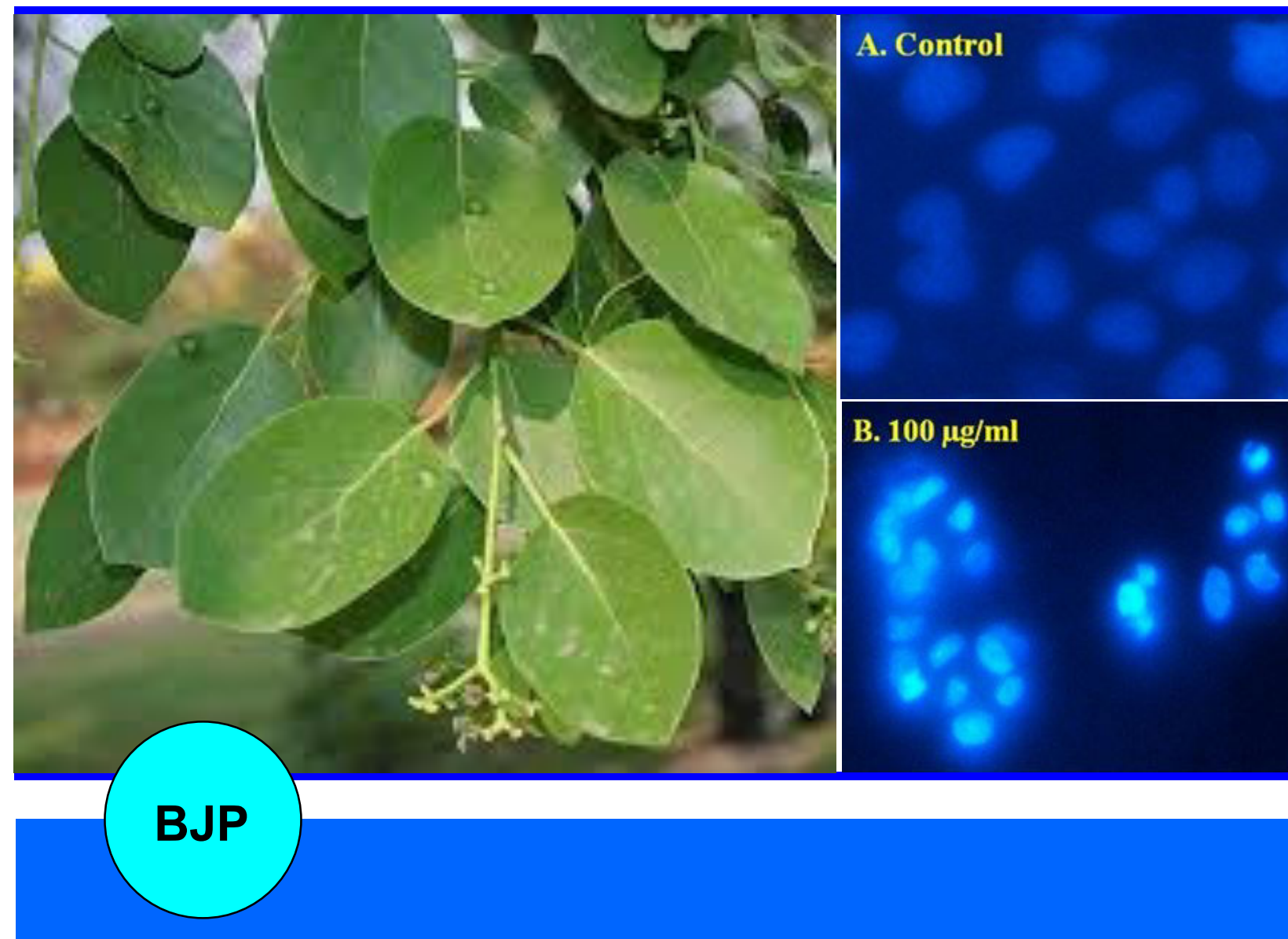

Bangladesh Journal of Pharmacology

Research Article

Anti-cancer activity and apoptosis inducing effect of methanolic extract of Cordia dichotoma against human cancer cell line 


\section{Anti-cancer activity and apoptosis inducing effect of methanolic extract of Cordia dichotoma against human cancer cell line}

\section{Md. Azizur Rahman and Arshad Hussain}

UP-CST Sponsored Project Lab, Faculty of Pharmacy, Integral University, Lucknow 226026, Uttar Pradesh, India.

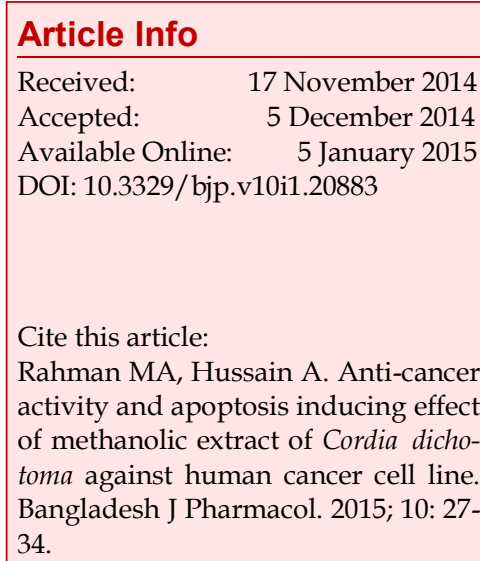

\section{Article Info}

\begin{abstract}
MTT assay and DAPI staining test were performed to evaluate the anticancer potential and to assess apoptosis inducing effect of the methanolic extract of Cordia dichotoma leaves (MECD) against human cervical cancer cell line (HeLa). Changes in MMP and intracellular ROS level were also assessed by JC-1 and DCFH-DA staining. Total phenolic contents were determined by colorimetric principle. Levels of statistical significance were determined by One-way analysis of variance followed by Dunnett's posttest. Results showed that MECD with obtained $\mathrm{IC}_{50}$ of $202 \mu \mathrm{g} / \mathrm{mL}$ inhibited in vitro proliferation of human cervical cancer cells and induced apoptosis indicating its promising anti-cancer activity as compared to the standard tamoxifen with obtained $\mathrm{IC}_{50}$ of $48 \mu \mathrm{g} / \mathrm{mL}$. Total phenolic contents was found to be $176.5 \mathrm{mg}$ GAE/g dried extract. It was concluded that MECD possess promising anti-cancer activity and induce apoptosis.
\end{abstract}

\section{Introduction}

Cancer is one of the leading causes of death (Jemal et al., 2009). Chemotherapy is an important option for the management of cancer in the clinical settings apart from the utility of surgical operations and irradiation. Medicinal plants are one of the major sources of chemotherapy drugs in modern as well as traditional medicine throughout the world (Suri et al., 1992). Phytochemicals or extracts from them have positive effects against cancer, compared with chemotherapy or recent hormonal treatments (Wu et al., 2002). Phenolics like coumarins, flavonoids, stilbenes, tannins, lignans and lignins are among the most widely occurring secondary metabolites in the medicinal plants. These phenolics are known to have anti-cancer activity on various cancer cell lines and induce apoptosis (Owen et al., 2000).

At present MTT assay is widely used for assessment of cell viability and proliferation studies (Berridge et al., 2005). A yellowish aqueous solution of MTT, on reduction in the cytoplasm by dehydrogenases and reducing agents like $\mathrm{NADH}$, yields a lipid soluble purple colored MTT formazan (Berridge et al., 1996). It is currently thought that the amount of formazan is directly proportional to the number of viable cells (van Meerloo et al., 2011).

The cells in which the DNA or other components are irreversibly damaged by various causes under normal conditions undergo programmed cell death called as apoptosis. These cells undergo serial structural and molecular changes during the process of apoptosis characterized by plasma membrane blebbing, chromatin compaction, DNA fragmentation, cell shrinkage and collapse of the cell into small intact fragments called as apoptotic bodies (Borner, 2003). DAPI, a DNA-specific dye that displays a blue fluorescence, can pass through intact and living cell membrane but apoptosis increases cell membrane permeability and its uptake leaving a stronger blue fluorescence (Bold et al., 1997).

The disruption of active mitochondria is a distinctive feature of the early stages of apoptosis. It includes changes in the mitochondrial membrane potential (MMP) and redox potential (Han et al., 2006). A dualemission potential-sensitive flouroprobe JC-1 is a 
mitochondrion-selective dye. In normal cells, due to high MMP (polarized mitochondria), the dye concentrates in the mitochondrial matrix and it forms red fluorescent aggregates (J-aggregates). Any event that dissipates the MMP (depolarized mitochondria) prevents the accumulation of the JC- 1 dye in the mitochondria and thus, the dye is dispersed throughout the entire cell leading to a shift from red fluorescence (Jaggregates, $\lambda_{\max } \sim 590 \mathrm{~nm}$ ) to green fluorescence (JC-1 monomers, $\lambda_{\max } \sim 529 \mathrm{~nm}$ ) (Liu et al., 2007). A decrease in red/green ratio is indicative of apoptosis.

Many stimuli such as anti-cancer drugs prompt cells to produce ROS (Larrick and Wright, 1990; Simizu et al., 1998). These ROSs induce apoptosis (Aggeli et al., 2006). DCFH-DA can pass cell membranes and is cleaved by intracellular esterases to DCFH and thereby trapped within the cells. A variety of ROSs oxidize DCFH to the fluorescent DCF (2,7-dichlorofluorescein) resulting in fluorescence (Kim et al., 2006).

The medicinal plant Cordia dichotoma belonging to the family Boraginaceae is practiced in various indigenous systems of medicine and popular among the various ethnic groups in India for the cure of variety of ailments as an astringent, anthelmentic, diuretic, demulcent, anti -diabetic and expectorant. It is reported to have antioxidant, juvenomimetic, antifertility, anti-inflammatory and various other pharmacological activities (Choudhary et al., 1990; Agnihotri et al., 1987). Phenolics and carotenoids are mainly present in their leaves which have potent anti-oxidant activity and can show anti-cancer activity too (Owen et al., 2000; Valvi et al., 2011). The aim of study was thus designed for exploration purpose to evaluate anti-cancer potential and apoptosis inducing effect of methanolic extract of C. dichotoma leaves on human cervical cancer cell line, HeLa and to determine total phenolic content.

\section{Materials and Methods \\ Collection and authentication of plant parts}

Leaves of $C$. dichotoma Linn for the proposed study were collected from nearby region of Kukrail forest (Lucknow, Uttar Pradesh) and authenticated by National Botanical Research Institute (NBRI), Lucknow (authentication reference number NBRI/CIF/306/2012 dated 18/06/2012).

\section{Extract preparation}

Collected leaves of C. dichotoma Linn was shade dried and powdered. The dried coarse powder was subjected to Soxhlet extraction with methanol to get the crude extract. The powdered material was evenly packed in a Soxhlet extractor for extraction. The temperature was maintained on an electric heating mantle with thermostat control. Appearance of colorless solvent in the siphon tube was taken as the termination of extraction. Extract was filtered and then concentrated to dryness in a rotavapor under reduced pressure and controlled temperature.

\section{Instrumentation}

UV-spectrophotometer, incubator, microplate reader (BIORAD-680), $\mathrm{CO}_{2}$ incubator (Excella ECO-170, New Brunswick), inverted fluores-cent microscope (Nikon Eclipse Ti-S, Japan), inverted phase contrast microscope (Nikon Eclipse Ti-S, Japan).

\section{Materials and reagents}

Folin-Ciocalteu phenol reagent (FCR, Merck), dimethyl sulphoxide (DMSO, Merck, India), phosphate-buffered saline (PBS, Himedia), Eagle modified essential medium (EMEM media, Himedia), fetal calf serum (Himedia), methyl-thiazolyl-tetrazo-lium dye (MTT, Himedia), 2,7-dichlorodihydro-fluorescein diacetate (DCFH-DA, Sigma-Aldrich, USA), 4',6-diamidino-2phenylindole (DAPI, Himedia), para-formaldehyde (Himedia), Triton X-100 (Merck, India), 5,5',6,6'tetrachloro-1,1',3,3' -tetraethylbenzimidazolcarbocyanine iodide (JC-1, Sigma-Aldrich, USA), tamoxifen (Tam, Sigma-Aldrich, USA).

\section{Cell line culture}

Human cervix carcinoma cell line, HeLa was obtained from cell repository-National Centre for Cell Sciences, Pune, India. The HeLa cells were cultured in EMEM supplemented with $2.0 \mathrm{mM}$ L-glutamine,1.5 g/L $\mathrm{NaHCO}_{3}, 0.1 \mathrm{mM}$ non-essential amino acids (NEAA), and $1.0 \mathrm{mM}$ sodium pyruvate and supple-mented with $10 \%(\mathrm{v} / \mathrm{v})$ fetal calf serum. Cells were grown at $37^{\circ} \mathrm{C}$, $5 \% \mathrm{CO}_{2}$ in a humidified air.

\section{Evaluation of total phenolic content}

Total phenolic content in the extract MECD was determined with Folin-Ciocalteu phenol reagent using gallic acid as the standard (Taga et al., 1984). $0.4 \mathrm{~mL}$ of the extract dissolved in $95 \%$ ethanol was added to $8 \mathrm{~mL}$ of $2 \%$ sodium carbonate solution. After $2 \mathrm{~min}, 0.4 \mathrm{~mL}$ of $50 \%$ FCR was added to the mixture which was then incubated at $30^{\circ} \mathrm{C}$ for half an hour. A reagent blank was prepared by mixing $0.4 \mathrm{ml}$ of $95 \%$ ethanol, $8 \mathrm{~mL}$ of $2 \%$ sodium carbonate solution and $0.4 \mathrm{~mL}$ of $50 \%$ FCR. Absorbance (Abs) was measured at $\lambda_{\max } 718 \mathrm{~nm}$ by a UV-spectrophotometer and compared to gallic acid calibration curve. Gallic acid calibration curve was established using different concentrations (50-500 $\mu \mathrm{g} /$ $\mathrm{ml}$ ) of gallic acid dissolved in 95\% ethanol. All analyses were run in triplicate and mean values were calculated. Result was expressed as 'mg GAE/g' dried extract (GAE: Gallic Acid Equivalent).

\section{Evaluation of anti-cancer activity}

Evaluation of anti-proliferative activity by MTT assay

The anti-proliferative activity of extract MECD was evaluated by MTT reduction assay (Chowrasia et al., 
2013). The cells $\left(1 \times 10^{4}\right)$ were seeded in $100 \mu \mathrm{L}$ complete medium in each well of the 96-well culture plate for 24 hours at $37^{\circ} \mathrm{C}$ and $5 \% \mathrm{CO}_{2}$ in a humidified air to enable them to adhere properly to the 96-well polystyrene culture plate. Extract MECD was dissolved in minimum amount of DMSO and then diluted to the desired concentrations $(25,50,100,300$ and $500 \mu \mathrm{g} / \mathrm{mL})$ in the medium and added to the wells with exponentially growing cells in triplicate as per experimental design. The concentration of DMSO used in the experiment never exceeded $1.25 \%$, which was found to be non-toxic to cells. After 21 hours of treatment, extract plus media was replaced with fresh media and $10 \mu \mathrm{L}$ of MTT $(5 \mathrm{mg} / \mathrm{mL}$ of media without phenol red and serum) solution was added in each well and the plate was further incubated for another 3 hours at $37^{\circ} \mathrm{C}$ until purple, lipid soluble formazan crystals developed. Then, the supernatant was discarded from each well and $100 \mu \mathrm{L}$ of DMSO was added to each well to dissolve formazan crystals by vigorous machine shaking for $10 \mathrm{~min}$ at $37^{\circ} \mathrm{C}$. The absorbance was recorded at $540 \mathrm{~nm}$ by a microplate Elisa reader using wells without extract as control and tamoxifen as standard. Plates were normally recorded within 1 hour of adding the DMSO.

The percentage cell viability was calculated as per the formula given below

$\%$ Cell viability $=[($ Absorbance of treated $) /$ (Absorbance of control)] $\times 100$.

The plot of \% cell viability versus sample concentration was used to calculate the concentration lethal to $50 \%$ of the cells $\left(\mathrm{IC}_{50}\right)$. The cellular morphology was also observed under inverted phase contrast microscope.

\section{Induction of apoptosis}

Cell morphological analysis of apoptotic cells with DAPI staining

The apoptotic induction by MECD was analyzed by staining with fluorescent nuclear dye DAPI to identify the condensation and fragmentation of nucleic DNA of the apoptotic cells (Lewandowska et al., 2013). The cells $\left(1 \times 10^{4}\right)$ were seeded in $100 \mu \mathrm{L}$ complete medium in each well of the 96-well culture plate for 24 hours at $37^{\circ}$ $\mathrm{C}$ and $5 \% \mathrm{CO}_{2}$ in a humidified air to enable them to adhere properly to the 96-well polystyrene culture plate. Extract was dissolved in minimum amount of DMSO and then diluted to the desired concentrations (100 and $300 \mu \mathrm{g} / \mathrm{mL}$ ) in the medium and added to the wells with exponentially growing cells in triplicate as per experimental design. After 24 hours of treatment, extract plus media was removed. Cells were then washed with PBS and fixed in $4 \%$ paraformaldehyde for $10 \mathrm{~min}$. Subsequently, the cells were permealized with permealizing buffer ( $3 \%$ paraformaldehyde and $0.5 \%$ Triton X-100) and stained with $50 \mu \mathrm{L}$ of DAPI with a final concentration of $1 \mu \mathrm{g} / \mathrm{mL}$. After 1 hour, the cells were observed for the intensity of fluorescence and cells having fragmented and condensed nuclei. The images were taken using a fluorescent microscope. The cells having fragmented and condensed nuclei were considered as apoptotic cells.

\section{Assessment of mitochondrial membrane potential of apoptotic cells with JC-1 dye}

The cells $\left(1 \times 10^{4}\right)$ were grown in 24 -well plate and then treated with increasing concentra-tions of extract (100 and $300 \mu \mathrm{g} / \mathrm{mL}$ ) as above. After 24 hours exposure time, the treated cells were washed with PBS and stained with $50 \mu \mathrm{L}$ of JC-1 dye with a final concentration of $2 \mu \mathrm{g} / \mathrm{mL}$ in EMEM media with-out phenol red. It was incubated in dark at $37^{\circ} \mathrm{C}$ for $30 \mathrm{~min}$. A decrease in mitochondrial depolarization patterns of cells by means of a shift from red fluores-cence to green fluorescence was then examined and photographed using inverted fluorescent microscope (Hausott et al., 2003). A decrease in red/green ratio was taken as indicative of apoptosis.

\section{DCFH-DA staining test for detection of intracellular} reactive oxygen species (ROS) level

Microscopic fluorescence imaging was used to study ROS generation in HeLa cells after exposure to different concentrations of extracts (Ahamed et al., 2013). The cells $\left(1 \times 10^{4}\right)$ were grown in 24-well plate and then treated with increasing concentrations of extract (100 and $300 \mu \mathrm{g} / \mathrm{mL}$ ) as above. After exposure, cells were incubated with DCFH-DA $(10 \mathrm{mM})$ as the fluorescence agent for $30 \mathrm{~min}$ at $37^{\circ} \mathrm{C}$. The reaction mixture was aspirated and replaced by $200 \mu \mathrm{L}$ of PBS in each well. The plates were kept on a shaker for $10 \mathrm{~min}$ at room temperature in the dark. An inverted fluorescence microscope with a CCD cool camera was used to analyze intracellular fluorescence of cells. Increased intensity of intracellular fluorescence was indicative of increased level of generated ROS.

\section{Statistical analysis}

Data was expressed as mean \pm SEM of pooled results obtained from at least three indepen-dent experiments. Levels of statistical significance were determined by one-way analysis of variance (ANOVA) followed by Dunnett's least significant difference posttest for multiple comparisons using the GraphPad Prism program. Significance level was considered as $\mathrm{p}<0.05$.

\section{Results}

From the gallic acid calibration curve, total phenolic content in MECD was found to be $176.4647 \mathrm{mg}$ GAE/g dried extract (Figure 1 and Table I).

The present work demonstrated the antiproliferative effects of extract in cervical cancer cells, HeLa. It was found that as the concentration of extract was increa- 
Table I

Evaluation of total phenolic content in methanolic extract of Cordia dichotoma leaves

\begin{tabular}{|c|c|c|c|c|c|c|}
\hline \multirow{8}{*}{$\begin{array}{l}\text { Standard } \\
\text { (Gallic acid) }\end{array}$} & $\begin{array}{l}\text { Conc. }(\mu \mathrm{g} / \\
\mathrm{mL})\end{array}$ & $\begin{array}{l}\text { Observed } \\
\text { absorbance }\end{array}$ & $\begin{array}{l}\text { Observed } \\
\text { absorbance }\end{array}$ & $\begin{array}{l}\text { Observed } \\
\text { absorbance }\end{array}$ & $\begin{array}{l}\text { Observed absorb- } \\
\text { ance }\end{array}$ & $\begin{array}{l}\text { Phenolic content (mg } \\
\text { GAE/g dried extract) }\end{array}$ \\
\hline & & $1^{\text {st }}$ & $2^{\text {nd }}$ & $3^{\text {rd }}$ & (Mean + SEM) & \\
\hline & 50 & 0.0008 & 0.0009 & 0.0010 & $0.0009+0.00006$ & \\
\hline & 100 & 0.0840 & 0.0850 & 0.0860 & $0.0850+0.00058^{a}$ & \\
\hline & 200 & 0.2562 & 0.2600 & 0.2680 & $0.2614+0.00348^{a}$ & \\
\hline & 300 & 0.4743 & 0.4796 & 0.4876 & $0.4805+0.00387 a$ & \\
\hline & 400 & 0.6735 & 0.6801 & 0.6870 & $0.6802+0.00390^{a}$ & \\
\hline & 500 & 0.9000 & 0.9082 & 0.9131 & $0.9071+0.00382^{a}$ & \\
\hline Test (Extract) & 1000 & 0.2368 & 0.2371 & 0.2383 & $0.2374+0.0005^{a}$ & 176.4647 \\
\hline
\end{tabular}

Values are expressed as mean $\pm \operatorname{SEM}(n=3)$. aindicates $\mathrm{p}<0.001$, when compared with $50 \mu \mathrm{g} / \mathrm{mL}$ group

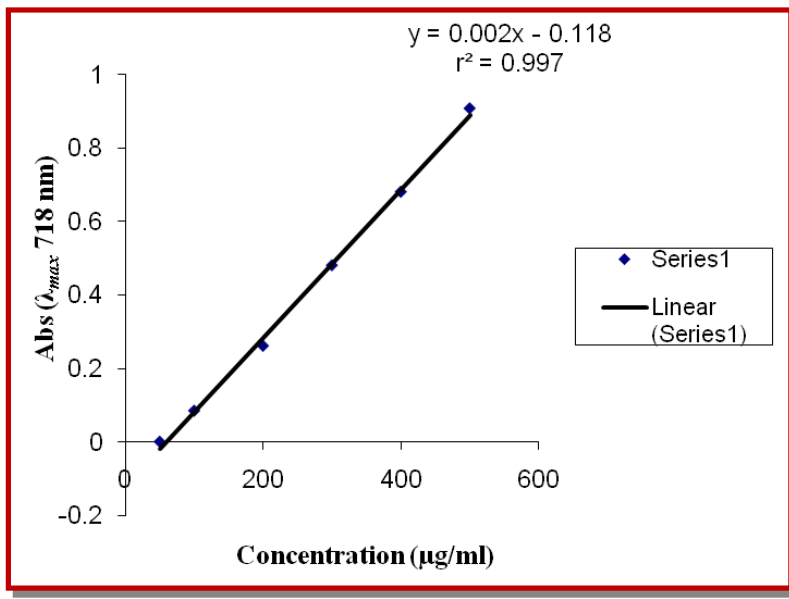

Figure 1: Gallic acid calibration curve (Abs vs Conc) for evaluation of total phenolic content in methanolic extract of Cordia dichotoma leaves

sing, cells were detaching themselves from the surface and losing their membrane permeability, changing to either circular or necrotic cells and increasing clumped cells with condensed cytoplasm demonstrating dose dependent antiproliferative effect of the extracts. From the graphical plot, $\mathrm{IC}_{50}$ value of MECD was found to be $202 \mu \mathrm{g} / \mathrm{mL}$ as compared to the standard tamoxifen with an $\mathrm{IC}_{50}$ value of $48 \mu \mathrm{g} / \mathrm{mL}$ (Table II \& III and Figure 2 \& $3)$.

Extract induced morphological changes such as cell shrinkage, rounding of cells and membrane blebbing which depict the induction of apoptosis. Supplementary photographs taken (Figure 4) have depicted the details of DAPI staining of HeLa cells. It was noted that the number of cells showing signs of apoptosis (cells that have brightly fluoresced and fragmented nucleus) were more in extract treated groups than the control group. It is clearly evident that different doses of extract have induced apoptosis and DNA condensation in cells with varying intensity in dose dependent manner.

From the photographs taken (Figure 5) using inverted fluorescent microscope, it is evident that a decrease in mitochondrial depolarization pa-tterns of cells and a shift from red (J-aggregates) to green fluorescence (JC-1

Table II

Effect of methanolic extract of Cordia dichotoma leaves on viability of HeLa cell line

\begin{tabular}{|c|c|c|c|c|c|c|c|}
\hline \multirow{2}{*}{$\begin{array}{l}\text { Conc. of } \\
\text { MECD }\end{array}$} & \multicolumn{3}{|c|}{ Observed absorbance after treatment } & \multicolumn{4}{|c|}{ Percent (\%) cell viability after treatment } \\
\hline & $1^{\text {st }}$ & $2^{\text {nd }}$ & $3^{\text {rd }}$ & $1^{\text {st }}$ & 2nd & $3^{\text {rd }}$ & Mean + SEM \\
\hline 0 (control) & 0.577 & 0.543 & 0.524 & 100 & 100 & 100 & $100+0.0$ \\
\hline 25 & 0.509 & 0.512 & 0.511 & 88.2 & 94.2 & 97.5 & $93.3+2.7^{a}$ \\
\hline 50 & 0.493 & 0.466 & 0.463 & 85.4 & 85.8 & 88.3 & $86.5+0.9^{b}$ \\
\hline 100 & 0.356 & 0.346 & 0.340 & 61.6 & 63.7 & 64.8 & $63.4+0.9^{b}$ \\
\hline 300 & 0.227 & 0.219 & 0.218 & 39.3 & 40.3 & 41.6 & $40.4+0.6^{b}$ \\
\hline 500 & 0.119 & 0.113 & 0.124 & 20.6 & 20.8 & 23.6 & $21.6+0.9 b$ \\
\hline
\end{tabular}

Values are expressed as mean $\pm \operatorname{SEM}(\mathrm{n}=3)$. ${ }^{\text {indicates }} \mathrm{p}<0.05(\mathrm{P}=0.026) ;{ }^{\mathrm{b}} \mathrm{p}<0.001$, when compared with control group $(0 \mu \mathrm{g} / \mathrm{mL})$ 


\section{Table III}

Effect of standard tamoxifen on viability of HeLa cell line

\begin{tabular}{|c|c|c|c|c|c|c|c|}
\hline \multirow{2}{*}{$\begin{array}{l}\text { Conc. of } \\
\text { tamoxifen }\end{array}$} & \multicolumn{3}{|c|}{ Observed absorbance after treatment } & \multicolumn{4}{|c|}{ Percent (\%) cell viability after treatment } \\
\hline & $1^{\text {st }}$ & $2^{\text {nd }}$ & $3^{\text {rd }}$ & $1^{\text {st }}$ & $2^{\text {nd }}$ & 3rd & Mean + SEM \\
\hline 0 (control) & 0.577 & 0.543 & 0.524 & 100 & 100 & 100 & $100+0.0$ \\
\hline 10 & 0.439 & 0.422 & 0.431 & 76.0 & 77.7 & 82.2 & $78.6+1.8^{a}$ \\
\hline 25 & 0.383 & 0.386 & 0.391 & 66.3 & 71.0 & 74.6 & $70.6+2.3^{a}$ \\
\hline 50 & 0.276 & 0.266 & 0.257 & 47.8 & 48.9 & 49.0 & $48.6+0.3^{a}$ \\
\hline 100 & 0.093 & 0.119 & 0.098 & 16.1 & 21.9 & 18.7 & $18.9+1.6^{\mathrm{a}}$ \\
\hline
\end{tabular}

Values are expressed as mean \pm SEM $(n=3)$. aindicates $\mathrm{p}<0.001$, when compared with control group $(0 \mu \mathrm{g} / \mathrm{mL})$

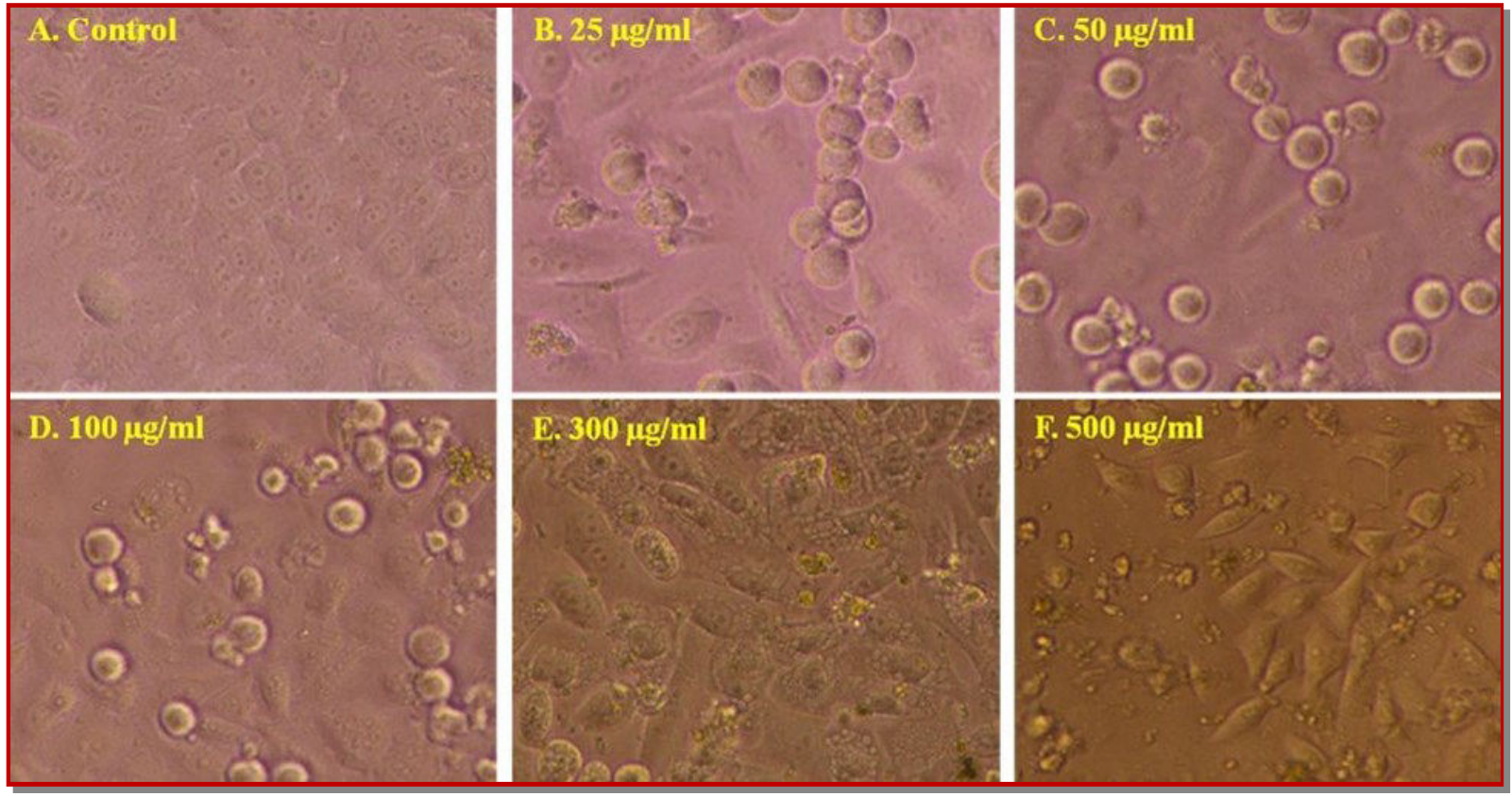

Figure 2: Effect of methanolic extract of Cordia dichotoma leaves during MTT assay for evaluation of antiproliferative activity: (A) Healthy HeLa cancerous cells attached to the surface, (B) Shape of cells changing to circular, (C) Almost circular and detached cells, (D) Detached and circular cells, (E) Completely detached, clumped cells with condensed cytoplasm, and (F) Completely dead and necrotic cells

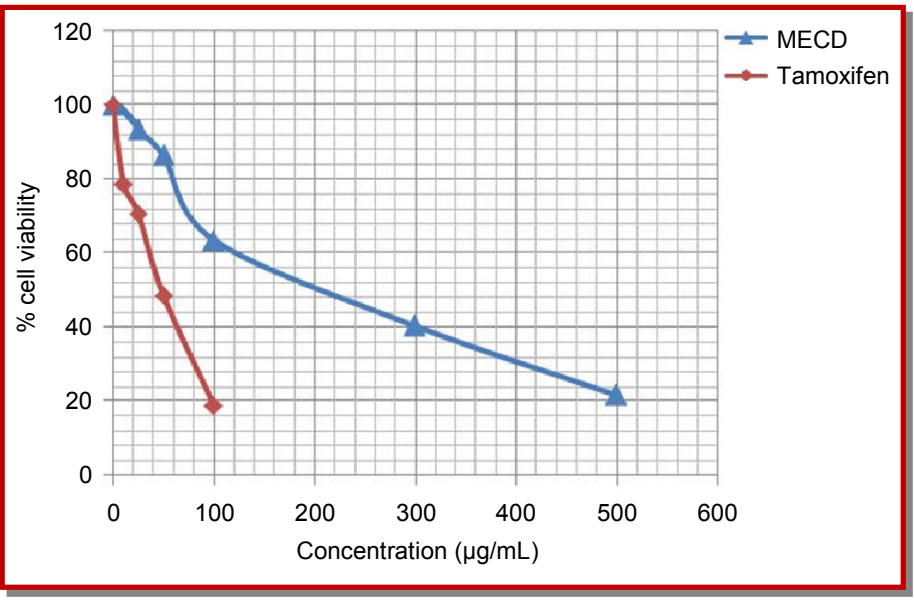

Figure 3: Percent cell viability vs concentration plot for the evaluation of antiproliferative activity of methanolic extract of Cordia dichotoma leaves by MTT assay monomers) have taken place in extract treated cells with varying intensity depending upon the dosage indicative of apoptosis was induced.

From the photographs taken (Figure 6) using inverted fluorescent microscope, it is evident that extract treated cancer cells stained with DCFHDA become more fluorescent with increased dosage indicative of significant intracellular ROS accumulation inducing apoptosis. Cells treated with extract emitted bright fluorescence with deformed morphology because of disturbance in the integrity of plasma membrane due to ROS generation.

\section{Discussion}

Plant-derived natural products are playing an 


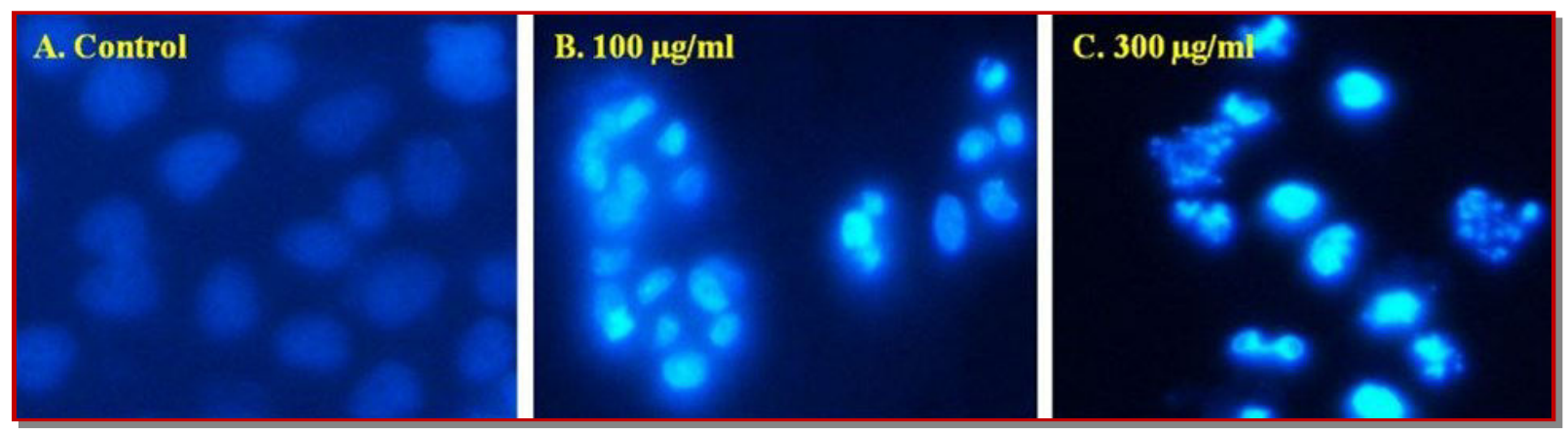

Figure 4: Cell morphological analysis of MECD induced apoptotic cells with DAPI staining: (A) Healthy HeLa cancerous cells without blue fluorescence, (B) Apoptotic bodies with blue fluorescence and nuclear or chromatin condensation, and (C) Apoptotic bodies with bright blue fluorescence and more nuclear or chromatin condensation

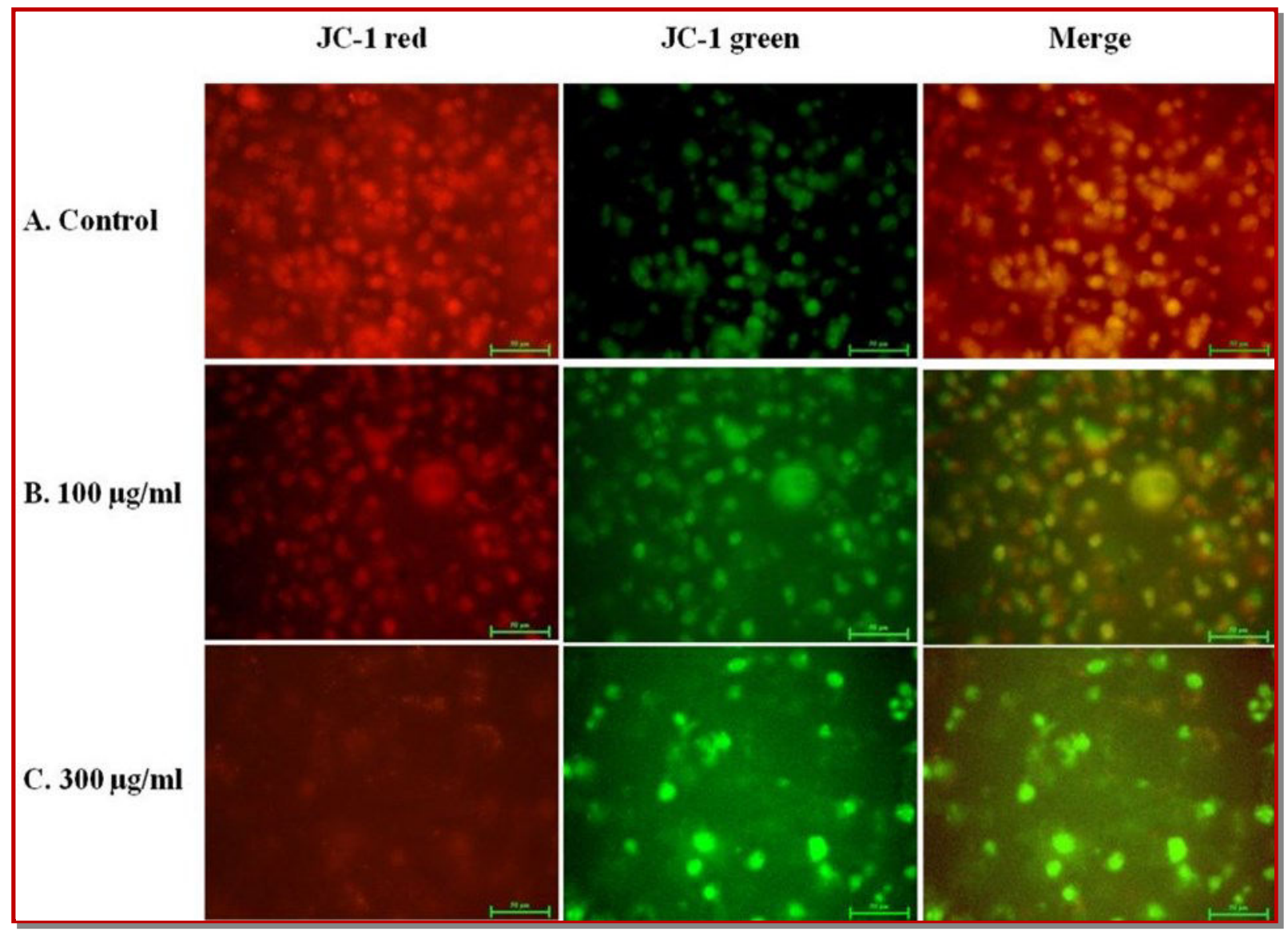

Figure 5: Assessment of mitochondrial membrane potential of MECD induced apoptotic cells with JC-1 dye: (A) Healthy HeLa cancerous cells with highly polarized mitochondria accumulating the JC-1 dye in the mitochondrial matrix and forming bright red fluorescent J-aggregates. There is no green fluorescence indicative of absence of apoptosis, (B) Slight apoptotic cells with slight depolarized mitochondria slightly preventing the accumulation of the JC-1 dye in the mitochondrial matrix leading to a shift from slight red fluorescence (J-aggregates, $\sim 590 \mathrm{~nm}$ ) to slight green fluorescence (JC-1 monomers, $\sim 529 \mathrm{~nm}$ ) indicative of slight apoptosis, and (C) More Apoptotic cells with highly depolarized mitochondria dispersing the JC-1 dye throughout the entire cell except mitochondria leading to a shift from negligible red fluorescence to bright green fluorescence indicative of more apoptosis

important role nowadays to cure various ailments. Cancer is one of the leading causes of death (Jemal et al., 2009). Phenolics are known to have anti-cancer activity on various cancer cell lines and induce apoptosis (Owen et al., 2000). Total phenolic content in MECD was found to be $176.4 \mathrm{mg} \mathrm{GAE} / \mathrm{g}$ dried extract.
All these findings prompted us to explore C. dichotoma as new potential anti-cancer agents. The $\mathrm{IC}_{50}$ values of both MECD and tamoxifen (standard) were obtained to know the extent of comparative anti-cancer activity of MECD. While, other parameters in the study were assessed for MECD only because of the relation of these 


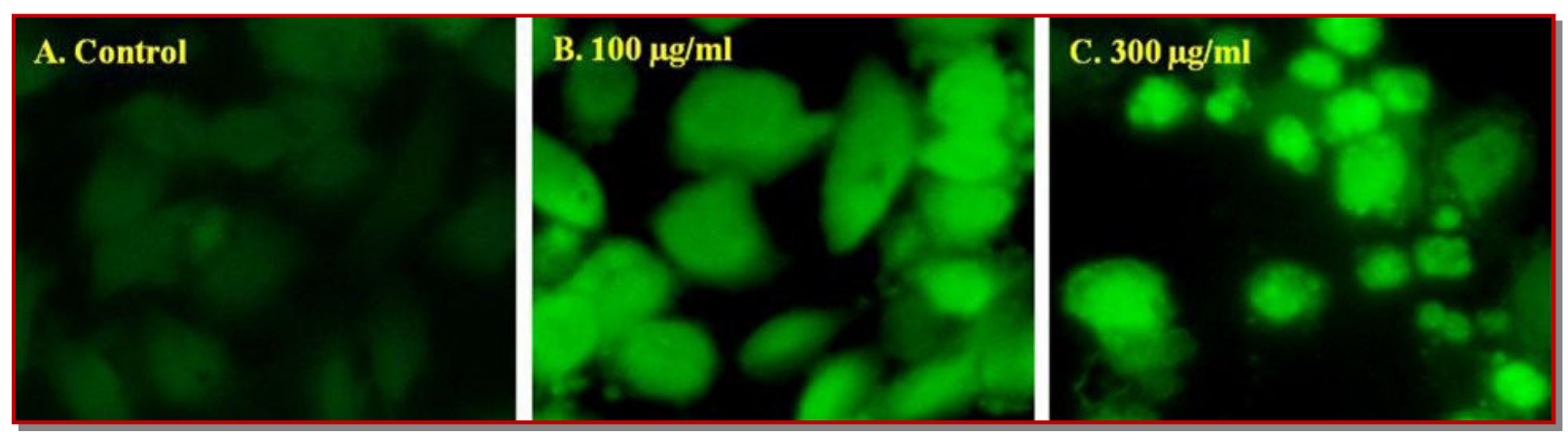

Figure 6: DCFH-DA staining test for detection of MECD induced intracellular ROS level: (A) Healthy HeLa cancerous cells without fluorescence (no ROS), (B) Extract treated cells with less fluorescence (less accumulated ROS), and (C) Extract treated cells with more fluorescence (more accumulated ROS)

parameters to the establishment of mechanism of action of any drug. And, here the main focus was on MECD. The present work demonstrated the antiproliferative effect of MECD on human cervical cancer cells, HeLa with an $\mathrm{IC}_{50}$ value of $202 \mu \mathrm{g} / \mathrm{mL}$ as compared to the standard tamoxifen with an $\mathrm{IC}_{50}$ value of $48 \mu \mathrm{g} / \mathrm{mL}$. The work also explored the underlying molecular mechanism occurring due to extract treatment.

Apoptosis is a common mode of action of chemotherapeutic agents including plant-derived natural products. Its induction is the key to success of plant derived natural products as anti-cancer agents (Sreelatha et al., 2011). After treatment with MECD, the increase of apoptotic cells including the characteristics of apoptotic cells and evident DNA fragmentations were observed which are the important hallmarks of apoptosis (Hu et al., 2010). Whereas, the control groups showed no increase of apoptotic cells and no evident of DNA fragments, it was indicated that MECD could specifically induce apoptosis of cancer cells. Detailed studies on mechanism of action of MECD on HeLa cancer cell line revealed that it induced apoptosis by various mechanisms either by DNA fragmentations or by mitochondrial depolarization or accumulation of ROS. Thus, the current work clearly indicates that methanolic extract of $C$. dichotoma leaves could be a novel potent cancer chemopreventive or chemotherapeutic agent for human cancer because of its promising activity and may be considered for further clinical studies in drug development.

Results of the study demonstrated the anti-cancer activity of MECD on human cervical cancer cells, HeLa. The study also explored the underlying molecular mechanism occurring due to extract treatment. Thus, the crude extract MECD may be a novel cancer chemopreventive or chemotherapeutic agent for human cervical and other cancers because of its promising activity and may be considered for further clinical studies in drug development.

\section{Acknowledgements}

Authors are thankful to the Integral University and University of Lucknow, Lucknow for providing the facilities related to the project work. Authors are thankful to Md Arshad and sahabjada, Molecular Endocrinology Lab, Department of Zoology, University of Lucknow, U.P. (India) for their full cooperation during the work.

\section{References}

Aggeli IK, Gaitanaki C, Beis I. Involvement of JNKs and p38MAPK/MSK1 pathways in $\mathrm{H} 2 \mathrm{O} 2$-induced upregulation of heme oxygenase-1 mRNA in H9c2 cells. Cell Signall. 2006; 18: $1801-12$

Agnihotri VK, Srivastava SD, Srivastava SK, Pitre S, Rusia K. Constituents from the seeds of Cordia obliqua as potential anti-inflammatory agents. Ind J Phram Sci. 1987; 49: 66-69.

Ahamed M, Ali D, Alhadlaq HA, Akhtar MJ. Nickel oxide nanoparticles exert cytotoxicity via oxidative stress and induce apoptotic response in human liver cells (HepG2). Chemosphere 2013; 93: 2514-22.

Berridge MV, Herst PM, Tan AS. Tetrazolium dyes as tools in cell biology: New insights into their cellular reduction. Biotechnol Annu Rev. 2005; 11: 127-52.

Berridge MV, Tan AS, McCoy KD, Wang R. The biochemical and cellular basis of cell proliferation assays that use tetrazolium salts. Biochemica. 1996; 4: 14-19.

Bold RJ, Termuhlen PM, McConkey DJ. Apoptosis, cancer and cancer therapy. Surg Oncol. 1997; 6: 133-42.

Borner C. The Bcl2 protein family: Sensors and checkpoints for life-or-death decisions. Mol Immunol. 2003; 39: 615-47.

Choudhary DN, Singh JN, Verma SK, Singh BP. Antifertility effects of leaf extracts of some plants in male rats. Indian J Exp Biol. 1990; 28: 714-16.

Chowrasia D, Karthikeyan C, Choure L, Sahabjada, Gupta M, Arshad M. Synthesis, characterization and anti-cancer activity of some fluorinated 3,6-diaryl-[1,2,4] triazolo[3,4-b] $[1,3,4]$ thiadiazoles. Arabian J Chem. 2013 (in press). 
Han J, Goldstein LA, Gastman BR, Rabinowich H. Interrelated roles for Mcl-1 and BIM in regulation of TRAIL-mediated mitochondrial apoptosis. J Biol Chem. 2006; 281: 10153-63.

Hausott B, Greger H, Marian B. Naturally occurring lignans efficiently induce apoptosis in colorectal tumor cells. J Cancer Res Clin Oncol. 2003; 129: 569-76.

Hu W, Lee SK, Jung MJ, Heo SI, Hur JH, Wang MH. Induction of cell cycle arrest and apoptosis by the ethyl acetate fraction of Kalopanax pictus leaves in human colon cancer cells. Bioresour Technol. 2010; 101: 9366-67.

Jemal A, Siegel R, Ward E, Hao Y, Xu J, Thun MJ. Cancer statistics, 2009. CA Cancer J Clin. 2009; 59: 225-49.

Kim YM, Lim JM, Kim BC, Han S. Cu, Zn-superoxide dismutase is an intracellular catalyst for the $\mathrm{H}(2) \mathrm{O}(2)$ dependent oxidation of dichlorodihydrofluorescein. Mol Cells. 2006; 21: 161-65.

Larrick JW, Wright SC. Cytotoxic mechanism of tumor necrosis factor-alpha. FASEB J. 1990; 4: 3215-23.

Lewandowska U, Szewczyk K, Owczarek K, Hrabec Z, Podsedek A, Koziolkiewicz M. Flavanols from Evening Primrose (Oenothera paradoxa) defatted seeds inhibit prostate cells invasiveness and cause changes in Bcl-2/Bax mRNA ratio. J Agric Food Chem. 2013; 61: 2987-98.

Liu T, Hannafon B, Gill L, Kelly W, Benbrook D. Flex-Hets differentially induce apoptosis in cancer over normal cells by directly targeting mitochondria. Mol Cancer Ther. 2007; 6: 1814-22.

Owen RW, Giacosa A, Hull WE, Haubner R, Spiegelhalder B, Bartsch H. The anti-oxidant/anti-cancer potential of phenolic compounds isolated from olive oil. Eur J Cancer. 2000; 36: 1235-47.

Simizu S, Takada M, Umezawa K, Imoto M. Requirement of caspase-3(-like) protease-mediated hydrogen peroxide production for apoptosis induced by various anti-cancer drugs. J Biol Chem. 1998; 273: 26900-07.

Sreelatha S, Jeyachitra A, Padma PR. Antiproliferation and induction of apoptosis by Moringa oleifera leaf extract on human cancer cells. Food Chem Toxicol. 2011; 49: 1270-75.

Suri RK, Chaudhari DC, Jaffer R. Commercially important medicinal plants from forest. J Ecol Bot Phytochem. 1992; 3: $129-40$.

Taga MS, Miller EE, Pratt DE. Chia seeds as a source of natural lipid anti-oxidants. J Am Oil Chem Soc. 1984; 61: 928-31.

Valvi S, Yesane DP, Rathod VS. Isolation of anti-oxidant enzymes from some wild edible fruits at mature and ripened stage rhizome. Curr Bot. 2011; 2: 53-55.

van Meerloo J, Kaspers GJ, Cloos J. Cell sensitivity assays: The MTT assay. Methods Mol Biol. 2011; 731: 237-45.

$\mathrm{Wu} \mathrm{J}, \mathrm{Wu}$ Y, Yang BB. Anti-cancer activity of Hemsleya amabilis extract. Life Sci. 2002; 71: 2161-70. 